\title{
Faktor - Faktor Pengembangan Ekowisata Pada Pantai Pathok Gebang dan Ujung Pakis di Desa Jengglungharjo
}

\author{
Dimas Pandjisetya Wiyandhita, dan Arwi Yudhi Koswara \\ Departemen Perencanaan Wilayah dan Kota Fakultas Teknik Sipil dan Perencanaan, Institut \\ Teknologi Sepuluh Nopember (ITS) \\ e-mail: arwiyudhi@gmail.com
}

\begin{abstract}
Abstrak-Desa Jengglungharjo memiliki lokasi yang masih alami serta memiliki objek wisata yang menarik yaitu wisata pantai serta wisata edukasi berupa konservasi penyu. Lokasi konservasi penyu berada pada Pantai Pathok Gebang dan Pantai Ujung Pakis serta penangkaran penyu yang berada pada permukiman warga desa. Jenis penyu yang berada pada lokasi wisata merupakan penyu yang tergolong dalam kategori kritis tingkat kepunahannya dan upaya penyelamatanya masih minim. Di lokasi lain banyak pantai serupa yang belum dikembangkan. Penelitian ini bertujuan menentukan faktor - faktor pengembangan ekowisata pada Pantai Pathok Gebang dan Pantai Ujung Pakis di Desa Jengglungharjo. harapanya nantinya faktor - faktor yang didapat dapat digunakan pada lokasi pantai lainya. Adapun faktor - faktor pengembangan ekowisata pada Pantai Pathok Gebang dan Pantai Ujung Pakis di Desa Jengglungharjo meliputi peningkatan optimalisisasi dari masing - masing faktor yaitu faktor lingkungan, faktor sosial budaya, faktor Pendidikan, faktor ekonomi, faktor kelembagaan, faktor keamanan dan faktor fasilitas dalam mendukung kegiatan wisata konservasi penyu.
\end{abstract}

Kata Kunci-Ekowisata, konservasi di pantai, penangkaran penyu.

\section{PENDAHULUAN}

$\mathrm{P}$ ENYU memiliki peran penting dalam memelihara keseimbangan ekosistem laut mulai dari memelihara ekosistem terumbu karang produktif hingga mentransfer nutrient-nutrient penting yang berasal dari lautan menuju pesisir pantai [1]. Penyu dapat dikatakan hewan reptil purba yang kehidupannya rentan akan gangguan seperti pergeseran fungsi lahan yang menyebabkan kerusakan habitat pantai dan ruaya pakan, kematian penyu akibat kegiatan perikanan, pengelolaan teknik - teknik konservasi yang tidak memadai, perubahan iklim, penyakit, pengambilan penyu dan telurnya serta ancaman predator merupakan faktor-faktor penyebab penurunan populasi penyu [2].

Indonesia memiliki enam dari tujuh jenis penyu yang berada di dunia, yaitu Penyu Hijau (Chelonia mydas), Penyu Sisik (Eretmochelys imbricata), Penyu Lekang (Lepidochelys olivacea), Penyu Belimbing (Dermochelys coriacea), Penyu Pipih (Natator depressus) dan Penyu Tempayan (Caretta caretta) [3]. Semua jenis penyu di Indonesia diberi status dilindungi oleh negara sebagaimana tertuang dalam PP Nomor 7 tahun 1999 tentang Pengawetan Jenis Tumbuhan dan Satwa.
Diberikanya status dilindungi oleh pemerintah dikarenakan untuk meminimalisir dari adanya tangan jail dari manusia yang ingin mengambil telur penyu atau penyu untuk di perjual belikan atau di konsumsi pribadi. Diberikannya status perlindungan bagi penyu masih kurang cukup untuk memulihkan atau setidaknya mempertahankan populasi penyu yang ada, dibutuhkan sikap dan tindakan nyata dalam melakukan pengelolaan konservasi penyu yang komperhensif, sistematis dan teratur [4].

Jenis penyu yang berada pada Desa Jengglungharjo adalah penyu belimbing, penyu hijau dan penyu sisik. Berdasarkan World Wide Fund (WWF), 2017 menyatakan bahwa 3 jenis penyu tersebut tergolong dalam kategori kritis tingkat kepunahannya. Sehingga diperlukan upaya perlindungan yang khusus dalam melindungi populasi penyu tersebut. Salah satu bentuk usaha menyelamatkan penyu laut di Indonesia khususnya adalah meningkatkan kesadaran masyarakat pada perlindungan penyu [5]. Upaya pelestarian dan penyelamatan penyu yang sejalan dengan pembangunan perekonomian masyarakat dapat dilakukan melalui pengembangan ekowisata.

Oleh karena itu perlu untuk mengetahui faktor - faktor yang berpengaruh dalam pengembangan ekowisata pada pantai Pantai Pathok Gebang dan Pantai Ujung Pakis di Desa Jengglungharjo. Sehingga nantinya dapat memberikan gambaran pengembangan konservasi penyu berdasarkan faktor - faktor ekowisata

\section{METODE PENELITIAN}

Dalam penelitian ini yang menjadi populasi adalah masyarakat Desa Jengglungharjo, pemerintah Kabupaten Tulungagung serta akdemisi. Dalam penentuan sampel mengunakan teknik sampling proporsive sampling dengan mengunakan teknik analisis stakeholders. Stakeholders yang digunakan dalam penelitian ini adalah sebagai berikut.

Tabel 1.

Pemetaan Stakeholder

\begin{tabular}{ccc}
\hline \hline No & Stakeholders & Responden \\
\hline $\mathbf{1}$ & Pemerintah & 1. Dinas Kebudayaan dan Pariwisata \\
& Kabupaten Tulungagung \\
& 2. Bapeda Kabupaten Tulungagung \\
& 3. Dinas Lingkungan Hidup Kabupaten \\
& Tulungagung \\
\hline \hline
\end{tabular}




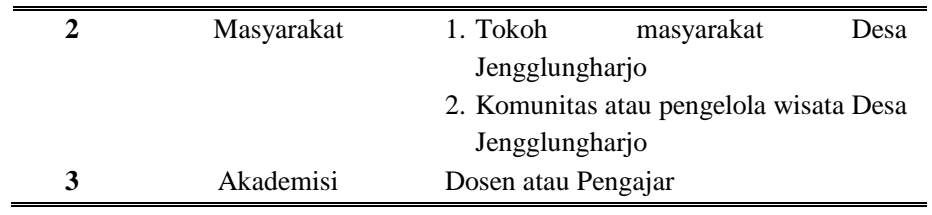

Metode pengumpulan data yang digunakan berdasarkan teknik pengumpulan observasi, wawancara dan penyebaran kuisioner/angket serta survei instansi dan literatur. Metode analisis yang digunakan adalah analisis delphi untuk mengetahui faktor - faktor pengembangan ekowisata pada pantai Pathok Gebang dan Ujung Pakis di Desa Jengglungharjo. Faktor dan variabel yang digunakan dalam penelitian ini anatra lain:

Tabel 2.

Faktor dan Variabel penelitan

\begin{tabular}{cl}
\hline \hline Faktor & Variabel \\
\hline Lingkungan & Konservasi \\
& Kondisi lingkungan \\
& Ekologi \\
Sosial Budaya & Pengalaman bagi wisatawan \\
& Pemberdayaan masyarakat lokal \\
Pendidikan & Edukasi pada SDM Lokal \\
& Edukasi pada wisatawan \\
Ekonomi & Peluang bagi masyarakat lokal \\
Kelembagaan & Manejemen pengelolaan \\
& Pelibatan stakeholder \\
& Pembatasan wisatawan \\
\hline
\end{tabular}

Sumber: Hasil Sintesa Kajian Pustaka,2016

\section{HASIL DAN PEMBAHASAN}

\section{A. Indentifikasi Jenis Penyu}

1. Penyu Hijau (Chelonia Mydas)

Penyu hijau memiliki nama ilmiah Chelonia mydas. Penyu ini memiliki ciri karapas yang berbentuk oval, memiliki warna kuning ke abu - abuan, memiliki bentuk yang tidak meruncing serta bentuk kepala yang bundar. Penyu hijau memiliki kedalaman sarang dalam bertelur antara $55-60 \mathrm{~cm}$ serta memiliki diameter $23-$ $25 \mathrm{~cm}$. Waktu bertelur penyu hijau pada malam hari yiatu pada pukul $21.00-02.00$, dan selang bertelur hampir 2 tahun sekali. Karakter habitat lokasi peneluran penyu hijau berada pada pantai yang terdapat pohon waru, pohon ketapang dan pohon pandan duri dengan jenis pasir pantai yang terdapat kurasa (mineral quartz).

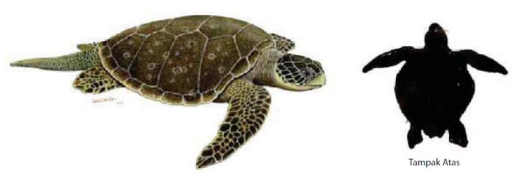

Gambar 1. Penyu Hijau

Sumber: pendoman teknis pengelolaan penyu, 2009

2. Penyu Sisik (Eretmochelys Imbricate)
Penyu sisik memiliki nama ilmiah Eretmochelys imbricate. Penyu sisik memiliki ciri bentuk karapas seperti jantung, meruncing pada bagian punggung, serta memiliki warna karapas coklat dengan beberapa variasi terang mengkilat. Tempat bertelur dari penyu sisik adalah pantai yang memiliki pasir koral atau pasir granit. Memiliki kedalaman saran paling dangkal jika dilihat dari penyu jenis lainya yaitu $35-42 \mathrm{~cm}$ serta diameter sarang $18-22 \mathrm{~cm}$. Waktu bertelur penyu sisik adalah siang dan malam hari, dan selang bertelur dari penyu sisik hampir 2 tahun. Karakter habitat lokasi peneluran penyu sisik berada pada lokasi pantai yang memiliki karakter butiran pasir koral hasil dari hempasan ombak / gelombang, serta memiliki warna pasir putih atau kekuningan.
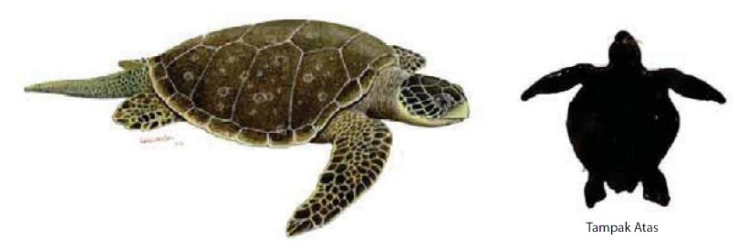

Gambar 2. Penyu Sisik

Sumber: pendoman teknis pengelolaan penyu, 2009

3. Penyu Belimbing (Dermochelys Coriacea)

Penyu Belimbing memiliki nama ilmiah Dermochelys coriacea. Penyu belimbing memiliki ciri punggung memanjang berbentuk buah belimbing, memiliki kepala sedang serta membundar, serta memiliki kaki depan yang panjang dengan punggung berwarna hitam hampir seluruhnya disertai bitnik - bitnik putih. Tempat bertelur dari penyu belimbing pada pantai yang luas dan panjang serta pada daerah tropis. Sarang dari telur penyu belimbing memiliki kedalaman $>100 \mathrm{~cm}$ serta memiliki diameter $30-35 \mathrm{~cm}$. Waktu bertelur penyu belimbing adalah malam hari yaitu pada pukul $20.00-$ 03.00 dan selang bertelur dari penyu belimbing hampir 2 tahun. Karakter habitat lokasi peneluran penyu belimbing memiliki kesamaan seperti penyu hijau yatu pada pantai yang terdapat pohon waru, pohon ketapang dan pohon pandan duri dengan jenis pasir pantai yang terdapat kurasa (mineral quartz).

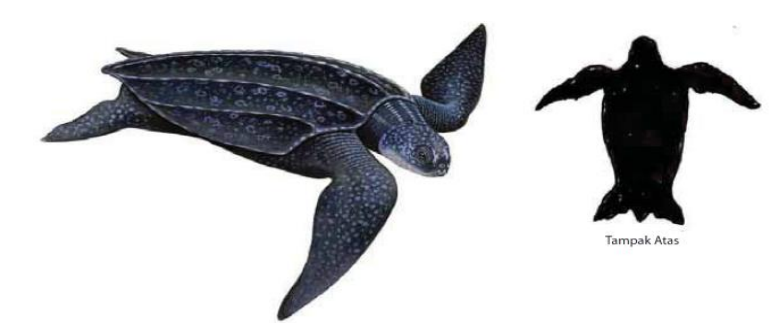

Gambar 3. Penyu Belimbing

Sumber: pendoman teknis pengelolaan penyu, 2009

\section{B. Lokasi Peneluran Penyu}

Lokasi peneluran penyu memiliki beberapa faktor yang perlu diperhatikan, yaitu lokasi peneluran atau pantai memiliki kemiringan yang landai. Karena kemampuan Penyu mencapai 
lokasi peneluran dengan kemiringan cukup besar tentunya akan membutuhkan energi lebih besar. Selain itu, mata penyu terbatas tidak dapat melihat pada sudut yang $150^{\circ}$ kebawah sehingga kemiringan yang landai dan lebar pantai yang tidak terlalu jauh akan lebih disukai penyu.

Vegetasi juga berpegaruh dalam proses peneluran penyu. Vegertasi yang terdapat di lokasi pantai sebaiknya tidak terlalu terbuka maupun juga tidak terlalu rimbun. Keberadaan vegetasi menjadi indikator keterlindungan bagi telur penyu dari limpasan air laut, predator dan memperlambat proses transmisi panas sinar matahari ke permukaan pasir. Perambatan dan penyerapan sinar matahari menjadi lebih lambat karena sinar matahari terserap lebih dulu oleh vegetasi sebelum ke permukaan pasir. Penyu lebih memilih lokasi yang minim dari aktifitas wisatawan. Aktifitas wisatawan yang tinggi dan sulit untuk dikendalikan kerap kali mengurangi kenyamanan penyu untuk melakukan peneluran.

\section{Mengidentifikasi Faktor yang berpengaruh dalam pengembangan ekowisata pada Pantai Pathok Gebang dan Pantai Ujung Pakis}

Analisis Delphi dilakukan untuk mengetahui dan melakukan validasi terhadap faktor yang telah ditentukan sebelumnya pada proses sintesa pustaka. Proses ini dilakukan guna mencari kesepakatan (consensus) dari stakeholder yang menjadi responden terkait dengan faktor dan variabel ekowisata dalam pengembangan Desa Jengglungharjo. Proses ini dapat dikatakan selesai apabila keseluruhan stakeholder menyepakati (consensus) seluruh faktor dalam pengembangan ekowisata. Dibawah ini merupakan analisis Delphi yang dilakukan sebanyak dua kali iterasi dalam mencapai kesepakatan (consensus).

Tabel 3.

Analisis Delphi Iterasi Pertama

\begin{tabular}{|c|c|c|c|c|c|c|c|c|}
\hline \multirow[t]{2}{*}{ "No } & \multirow[t]{2}{*}{ Faktor } & \multirow[t]{2}{*}{ Variabel } & \multicolumn{4}{|c|}{$\begin{array}{l}\text { Setuju (S) } \\
\text { Setuju (TS) } \\
\end{array}$} & \multicolumn{2}{|c|}{ Tidak } \\
\hline & & & 1 & 2 & 3 & 4 & 5 & 6 \\
\hline \multirow[t]{3}{*}{1} & Lingkung & Konservasi & $\mathrm{S}$ & $\mathrm{S}$ & $\mathrm{S}$ & $\mathrm{S}$ & $\mathrm{S}$ & $\mathrm{S}$ \\
\hline & an & Kondisi lingkungan & $\mathrm{S}$ & $\mathrm{S}$ & $\mathrm{S}$ & $\mathrm{S}$ & $\mathrm{S}$ & $\mathrm{S}$ \\
\hline & & Ekologi & $\mathrm{S}$ & $\mathrm{S}$ & $\mathrm{S}$ & $\mathrm{S}$ & $\mathrm{S}$ & $\mathrm{S}$ \\
\hline \multirow[t]{2}{*}{2} & Sosial & Pengalaman bagi wisatawan & S & S & $S$ & $\mathrm{~S}$ & $\mathrm{~S}$ & $\mathrm{~S}$ \\
\hline & Budaya & $\begin{array}{l}\text { Pemberdayaan masyarakat } \\
\text { lokal }\end{array}$ & $\mathrm{S}$ & S & $S$ & $\mathrm{~S}$ & $\mathrm{~S}$ & $S$ \\
\hline \multirow[t]{2}{*}{3} & Pendidika & Edukasi pada SDM Lokal & $\mathrm{S}$ & S & $\mathrm{S}$ & S & $\mathrm{S}$ & $S$ \\
\hline & $\mathrm{n}$ & Edukasi pada wisatawan & $\mathrm{S}$ & $\mathrm{S}$ & $\mathrm{S}$ & $\mathrm{S}$ & $\mathrm{S}$ & $\mathrm{S}$ \\
\hline 4 & Ekonomi & $\begin{array}{l}\text { Peluang bagi masyarakat } \\
\text { lokal }\end{array}$ & $\mathrm{S}$ & $\mathrm{S}$ & $\mathrm{S}$ & $\mathrm{S}$ & $\mathrm{S}$ & $\mathrm{S}$ \\
\hline \multirow[t]{4}{*}{5} & Kelembag & Manejemen pengelolaan & S & S & $S$ & S & $\mathrm{S}$ & $\mathrm{S}$ \\
\hline & aan & Pelibatan stakeholder & $\mathrm{S}$ & $\mathrm{S}$ & $\mathrm{S}$ & $\mathrm{S}$ & $\mathrm{S}$ & $\mathrm{S}$ \\
\hline & & Pembatasan Wisatawan & $\mathrm{T}$ & $\mathrm{T}$ & $\mathrm{T}$ & $\mathrm{T}$ & $\mathrm{T}$ & $\mathrm{T}$ \\
\hline & & & $\mathrm{S}$ & $\mathrm{S}$ & $\mathrm{S}$ & $\mathrm{S}$ & $\mathrm{S}$ & $\mathrm{S}$ \\
\hline
\end{tabular}

Keterangan:

1. Dinas Kebudayaan dan Pariwisata Kab. Tulungagung

2. Bapeda Kab. Tulungagung

3. Dinas Lingkungan Hidup Kab. Tulungagung

4. Tokoh masyarakat Desa Jengglungharjo

5. Komunitas atau pegelola wisata Desa Jengglungharjo (POKDARWIS)

6. Dosen atau pengajar

Hampir keseluruhan faktor disetujui oleh responden namun terdapat salah satu variabel dari faktor kelembagaan tidak di setujui oleh keseluruhan responden yaitu pada pembatasan wisatawan di anggap kurang setuju dikarenakan objek wisata tergolong baru perlu adanya pengembangan lokasi wisata dari wisatawan yang datang. Selain itu responden juga nembahkan beberapa variabel tambahan yaitu

1. Pos penjagaan

2. Rambu - rambu

3. Kamar mandi

4. Ruang infromasi

5. Kebudayaan masyarakat lokal

Karena pada iterasi pertama di dapatkan variabel tambahan, maka dari itu dilakukan iterasi yang kedua untuk mendapatkan kesepakatan (consensus).

\begin{tabular}{lllllllll}
\hline \hline No & Faktor & Variabel & \multicolumn{3}{l}{ Setuju (S) / Tidak Setuju } \\
& & $($ TS $)$ & & & & \\
& & 1 & 2 & 3 & 4 & 5 & 6 \\
\hline $\mathbf{1}$ & Sosial & Kebudayan Masyarakat & S & S & S & S & S & S \\
& budyaa & Lokal & & & & & & \\
$\mathbf{2}$ & Keamanan & Pos Penjagaan & S & S & S & S & S & S \\
& & Rambu - Rambu & S & S & S & S & S & S \\
$\mathbf{3}$ & \multirow{2}{*}{ Fasilitas } & Fasilitas Ruang Informasi & S & S & S & S & S & S \\
& & Kamar mandi & S & S & S & S & S & S \\
\hline \hline
\end{tabular}

Sumber: Hasil Analisis, 2017

Keterangan:

1. Dinas Kebudayaan dan Pariwisata Kab. Tulungagung

2. Bapeda Kab. Tulungagung

3. Dinas Lingkungan Hidup Kab. Tulungagung

4. Tokoh masyarakat Desa Jengglungharjo

5. Komunitas atau pegelola wisata Desa Jengglungharjo (POKDARWIS)

6. Dosen atau pengajar

Berdasarkan hasil dari analisis Delphi yang telah dilakukan mulai iterasi pertama hingga iterasi kedua, analisis Delphi yang dilakukan mencapai kesepakatan (consesnsus), maka di dapatkan faktor yang dapat mempengaruhi pengembangan Pantai Pathok Gebang dan Ujung Pakis dengan konsep ekowisata. Berikut adalah faktor dan variabel yang berpengaruh.

1. Faktor Lingkungan

- Konservasi

- Kondisi lingkungan

- Ekologi

2. Faktor Sosial budaya

- Pengalaman bagi wisatawan

- Pemberdayaan masyarakat lokal

- Kebudayaan masyarakat lokal

3. Faktor Pendidikan

- Edukasi pada SDM lokal

- Edukasi pada wisatawan

4. Faktor Ekonomi

- Peluang bagi masyarakat lokal

5. Faktor Kelembagaan

- Manejemen pengelolaan

- Pelibatan stakeholder

6. Faktor Keamanan

- Pos penjagaan 
- Rambu - rambu

7. Faktor Fasilitas

- Fasiltas ruang informasi

- Kamar mandi

\section{KESIMPULAN}

Berdasarkan hasil dari analisis didapatkan faktor - faktor dalam pengembangan ekowisata yaitu faktor lingkungan, faktor sosial budaya, faktor pendidikan, faktor ekonomi, faktor kelembagaan, faktor keamaan dan faktor fasilitas. Faktor faktor tersebut dibutuhkan dalam pengembangan ekowisata konservasi penyu pada Pantai Pathok Gebang dan Pantai
Ujung Pakis di Desa Jengglungharjo.

\section{DAFTAR PUSTAKA}

[1] K. Pitana, I., \& Diarta, Pengantar Ilmu Pariwisata. Yogyakarta: Andi, 2009.

[2] UNESCO, Panduan Dasar Pelaksanaan Ekowisata. 2009.

[3] Suharso, Perencanaan Objek Wisata dan Kawasan Pariwisata. PPSUB, 2009.

[4] D. Dkk, Pedoman Teknis Pengelolaan Konservasi Penyu. 2009.

[5] W. Kurniarum, M \& Prihanta, "Pengetahuan dan Sikap Masyarakat Terhadap Konservasi Penyu dan Ekowisata di Desa Hadiwarno Kabupaten Pacitan Sebagai Sumber Belajar Biologi," J. Pendidik. Bilogi Indones., 2015. 